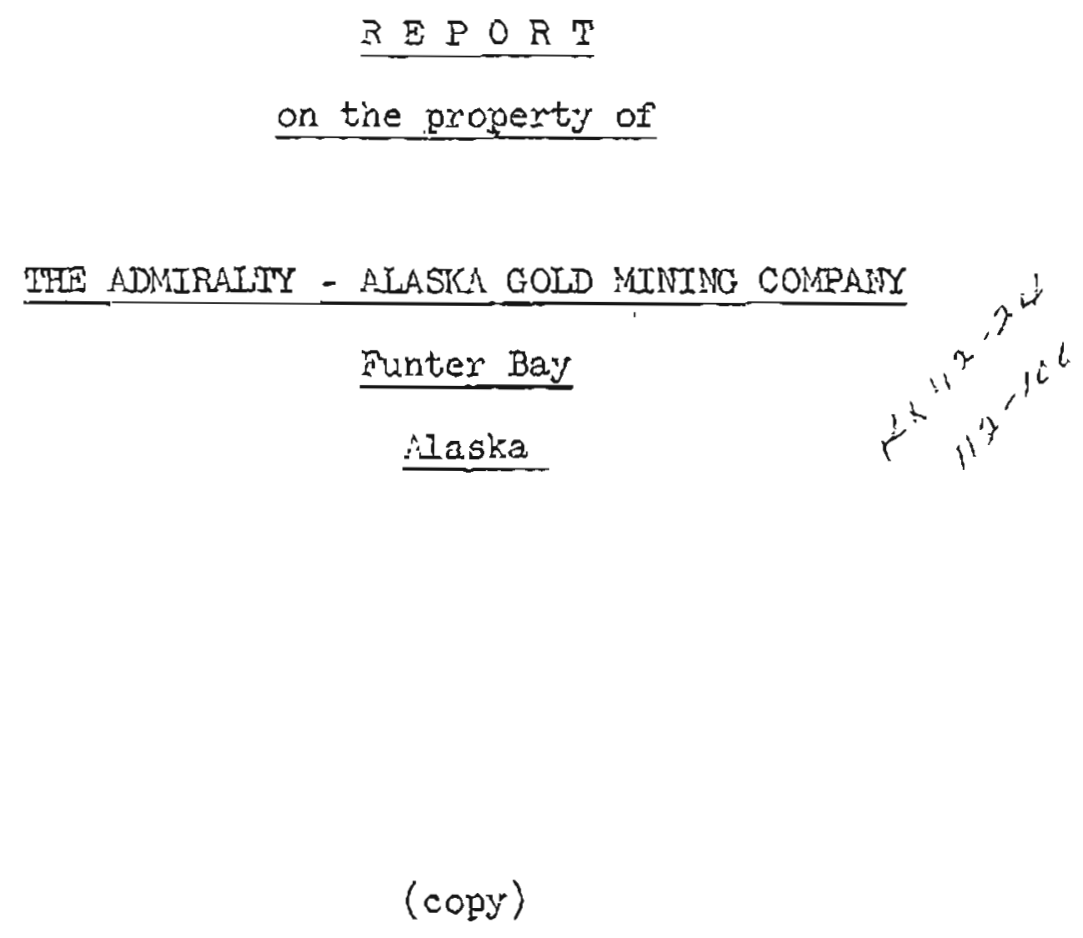

Bellingham, Washington

Certified Correct

April 23ra, 1929

HENRY M. EAKIN

Consulting Geologist 
PORTIARD

The writer has visited the property of The Admiralty-Alaska Gold Mining Company on three separate occaslons. Upon two of these he devoted considerable time to examination of the property, assay records and engineer reports from the view-point of economic geolocy. He has also examined the drill core produced in the course of underground exploretion of the Mertie vein.

The following text embodies the principle results of these studies. The data used is in all cases efther the result of personal observation or of a character that thoroughly accords with all related determinations and impressions of the writer.

\section{GENERAL INEORMATION}

The property includes about 100 mining claims or some 2,000 acres in all, fronting on the southeasterly shore of Funter Bay, Admiralty Island, Alaska. It thus fronts on a good harbor near a main traffic lane and enjoys freight rates similar to those of the Juneau mining district, eighteen miles to the East. Ruch of the property is heevily timoered with excellent stands of spruce and cedar, so that lumber to neet every possible need is available at cost of logging and milling. The climate is revorable to all year operations, with 
no excessive heat in summer, and little very cold weather at any tirne.

Precipitation is heavy and considerable storage is afforded by snowbanks that in places last well toward the end of summer. Moderete vater pover, already partly developed, is thus afforded by local runoff. Although susceptible to some further development local water power possibilities are inadequate for any very large demand. A large power site reported upon by the Geological Survey is said to be available some 20 miles distant from Funter Bay,

\section{TOPOGRAPHY}

A lowland belt about half a mile wide extends back from the shore of Funter Bay to the foot of the mountain slopes. Beyond this the mountains rise steeply toward the general upland axis of the island. The area of the property is thus divided topographically between undulatine plain 20 to 50 feet above sea level and mountain slope and upland that rise in a short distance from the level of the lowland to over 3000 feet.

Botil Lowland and mountain are bedrock features, developed oy the same agencies of stream and glaciel erosion. Their contrest is due to difference in resistance to erosion of their respective geologic formations. The difference between 


\section{$-3-$}

upland and lowlend parts of the area is thus not only topographic but geologic as well. In keeping with topographic and geologic difference there is also a wreat difference in vein formations and character of mineralization betreen uplend and lowland sections of the property.

\section{GENERAL GEOLOGY}

The rocks of the Funter Bay area in general represent a primary series of interbedded sediments and lava and secondary intrusive igneous rocks that range widely in age and composition. All excepting the younger intmusive rocks have undergone reglonal metarnorphism and, excepting limestone, which is now marble, are altered into various types of schist. Only the later intrusive rocks have escaped complete recrystailization and only a few of the most recent dike rocks have retained much of their original mineral composition.

The younger intmusive rocks of the lowland aree tend generally to be more acjd in type, finer in grain and to have had less metamorphic effect upon invaded rocks than corresponding members of the upland assemolage. While Eranitic and related types appear in lowland dikes and silla, the correspanding occurrences in the upiend region are dominantly gaobroic and finer grained rocks of extremely oasic composition.

The later instrusives of the lowland area axe mostiy 
dikes intruded along highly inclined or vertical fissures. Those of the upland include both dikes and sills that conform in shape and position to much more complex structural lines of veakness. The superior resistance to exosion of the upland rocks seems to be largely a result of their hordening under igceous influences or these relatively late basic intmusives.

\section{AITIERALIZATION}

A general feature of rock composition in the Tunte: Bay area that should be mentioned was first recognized and described by ifertie as follows:

"All the acidic and intemediate types of intrusive rocks examined oy the writer:.: contaln albite or oligoclase - elbite plagioclase feldspar, and albite is also of conmon occurrence among the schists and goeisoes. This feature is of more than passing interest when considered in relation to the soditic character of the intrusive rock at the Treadwell mines, on Douglas Island, about 15 miles to the east. It is not unliliely that mineralization at these two localities tock place at the same generel period and had a similar origin."

(Mertie, J. B. Buli. U.S. Geolo. Survey, lo. 714-3., 2. IIj, 1921)

Other features common to the two districts ano frequent occurrence ô calcite and quartz together in the same vein; association of ankerite and spilelertte with free gold, and vezy ride distrioution of finely disseminated pyrrhotite and traces or more of 
gold throughout rock formation of many different kinds and descrip. tions, also important differences in mineralization appear, particularly in the occurreace of complex sulphide ore in the Mertie dike at Funter Bey, which has no known counterpart in the Juneau area. The essential facts that seem well established are that both districts have had prolonged and complex histories of igneous activity, and that mineralization in both districts is of deep seated igneous origin and therefore, generally similar as regards possible downward extent.

\section{ORE DEPOSITS}

The ore deposits of major interest on the AdmiraltyAlaska property are the gold-quartz velns of the lower and upper grougs, and a sulphide deposit high up on the mountain that carries nickel, cobalt, copper and some gold. The former are true fisaure veins, the strongest standing close to the vertical. The sulphide deposit, known as the Mertie vein is altered basic rock, much velned and impregnated with sulphides, that appears in the natural exposure to have the form of an intrusive sill that alps about $32^{\circ}$ eastward beneath the mountain. Similar ore, however, was penetrated by the drill at a point 600 feet almost directly beneath the surface outcrop.

Golâ also occurs as already stated, widely disseminated, generally in small quantity throughout most of the local rock formations. Seldom less than a trace, most frequently 20 to 40 cents a ton, and occasionally higher values have been obtained from 
practically every kind of rock on the property. Personel sampling by the writer and unquestionable assay procedure thoroughly checks with voluninous assay deta of the Company and other investigators bearing upon this aspect of gold occurrence. As yet no commercial depostt of this character has been proved. Higher taan average values were obtained, however, from an area of sillcipled slate soutbwest of the Heckler workings sufficient to justify further prospecting in that vicinity.

A fourth type of ore occurrence is one of zinc and lead found on the southerly part of the property in laminated quartz ore schist and slate. Layers of the rock in places are heavily impregnated wth sphalerite and gelena. Occasional narrow lenses of practically pure mineral are to be found. The occurrences examined by the writer were not of minable size.

\section{GOLD-GWARTZ VEINS}

Gold-quartz veins of the Aomiralty-Alaska property that have been most extensively developed are the Tellurium, Uncle Sam and King Bee veins of the lower group, and the Heckler Blanket vein of the upper group. All of these have been mined to some extent and the ores oroduced put througin the mill. The writer has no data on the tenor or ores milled during the earlier operation of the plant, but is informed that the later mill test results were in line whth estimated average values of ore frora the different veins as follows: 
Vein Value per ton

Tellurium............\$30.00

Uncle Sam;; ; .......... 10.00

King Bee.............. 6.00

Heckler............... 50.00

He is also informed that from $40 \%$ to $60 \%$ of the gold was recovered on the plates and much of the balance in the form of concentrates.

Tacom Smelten: records of three shipments of concentrates from the Admiralty-Alaska Gold lining Company in 1926 and 1927 show the following tenors in gold and silver:

$\begin{array}{lrc}\text { Smelter Lot } & \text { Gold } & \text { Silver } \\ & \text { oz. } & \text { oz. } \\ 2829 & 4.32 & 1.07 \\ 2340 & 4.69 & 0.74 \\ 2340-1 / 2 & 11.42 & 1.63\end{array}$

The average tenor of the concentrates referred to appears to have been about $6.81 \mathrm{oz}$. of gold and 1.15 oz. of silver to the ton with an average value of about $\$ 135.00$ to the ton.

The writer has examined voluminous assay records of samples taken from these veins by different investigators. The data indicates as an outstanding characteristic an extreme variability in tenor from sample to sample. Samples taken personally by the writer and assayed under proper control also indicate about the same range of variation. Since the quartz now exposed in the old workings is mostly that rejected in mining it appears that estimate of average tenor should be most reliably based upon records of actual production said to have been at a rate somewhat over $\$ 10.00$ a ton. 
Many veins besides those that have been actually mined occur in botin the Lowland and upland parts of the property. For the most part development work has stopped short of proving more than authentic fact of their occurrence. To attempt to estimate their average tenors is therefore quite impossible. The assay records applying to them show the same sort of variation as the different samples from the developed veins.

If the average gold content shourd bold at $\$ 10.00$ a ton, the gold quartz velns of the property could possibly support a moderate tonnage mining and miling operation. The veins of the lower group may reasonably be expected to persist downward in the same fashion that they do horizontally. Theis further development vould be a holstias proposition. Good practice might aim at production of 300 to 500 tons a day.

The Heckler vein as now revealed does not appear to fill a regular fissure thet can be counted on to persist for any specific distance. The contorted structure of the adjacent rocks and uneven thickness of its associated trachite dike suggest rathe: that no dependable estimate of its reserve tomage can be made aheed of actual development. Free gold is visible in parts of the depostt, other parts give low and nil assay returns. Further development work, preferably by drilling, appears vell justified.

The so-called "Big Lode" appears under recent development to be not a regular or continuous vein but ratier a succession of large out widely separated bodies of quartz, distributed elong the same general line of the Mertie dike. Moreover its sulphide mineral 
content resembles the Mertie rather than the proven gold-quartz vein type.

\section{THE MERTIE LODE}

The ivertie lode outcrops at the surface at an elevation of about 2000 feet and at a direct distance of about 6000 feet from the Admiralty-Alaska mill. It has been described by Buddington (Buddington, A. F., U. S. Geol. Survey, Bull. 783-B, 9. 46, 1926), as "a dike of troctolite, locally containing disseminations of sulghide blebs." He discusses the mineralogy of the rock as a whole 8s follows:

"The alke rock consists of about 55 per cent labradorite, 39 per cent olivine, 4 per cent pyroxene, and 2 per cent magnetite. The magnetite occurs both as minute crystals disseminated in the olivine and as grains interstitial to the pyroxene. The olivine occurs as grains of early crystallization in a eround. mass of labradorite with a diabasic texture. The pyroxene is wholly interstitial to the plagioclase. The olivine in places is partly to completely altered to aggregates of serpentine or talc and iron oxides. Carbonate, chlorite, actinolite, and biotite are present locally as secondury minerals. The serpentine and secondary minerals are of leter origin than the sulphides. The sulphides form irregular shaped bleos, locally in irregular velnlike forms for half an inch or so, interstitial to the silicate minerals. Generaliy the sulphides are molded against idimorphic crystal races of the silicates, but in places they corrode and partly replace the silicates. Wagnetite of two generations is preseat, the older occurring as abundant minute euhedral crystals disseminated througbout the silicates and the younger as larger grains interstitial to the silicates 
or as crystals and grains on the outer borders' of the sulphide blebs. Magnetite locally $\infty-$ curs as a group of crystals with perfect borders within the sulphides. In places it shows a little corrosion by the sulphides. Rarely pyrite crystals occur within the suiphide masses but are usually on their outer borders. The magnetite and pyrite were the first metallic minerals to crystallize. A littie chalcopyrite is present. It is restricted almost exclusively to the outer borders of the sulphide blebs and assurues elongate barrow shapes, with one side against the silicates and rounded borders against the pyrrhotite. It appears to orecede the pyrrhotite and pentlandite. The pentlandite occurs as stringlike veinlets crossing the pyrrhotite and as fringes bordering the pyrrhotite blebs, and has therefore crystallized later than the prrrhotite. The sulphides, though showing an order of crystallization, ere yet essentially contemporaneous and, taken as a whole, belong to a late stage in the consolidation of the dike magma and are themselves of magratic origin."

Further develcpment work on the Mertie lode after the time of Buddington's examination permitted the mriter to observe the bottor of the intrusive mess where it rests upon a finely fissile greenstone schist. The strike of the contact surface as far as exposed dipoed easterly about $32^{\circ}$ tovard the mountain. The upper contect of the igneous body also appears to dip in the same direction beneath a caoping of sreatly indurated graphitic slate. The structure thus indicated is that of an intmusive sill. Careful estinate of distance from point to point epproximately at right angles vith indicated dio gave 135 feet as minimum thickress of the mineralized portion of the intrusion.

$$
\text { Morthvard continuation of tine igneous member, for a }
$$


short distance at least, is indicated in a test pit about 50 feet from the axds of the discovery, cropping along tine cross cutting stream. Beyond this to the nortin, and elso southvard from the stream outcrop, bedrock is deaply covered by an apron of talue shed from the towering slate bluffs above. The orominence of the slate scarp seens quite likely due to metamorphic ertect of tine trocolite intrusion. The bluf̂̃s extend both north and south end, for several hundred feet, disola: about the same extreme degree of induration.

Subsequent to the rield exemination of the Mertie lode by the writer, referred to above, conslderable drilling has been done on it by the Company. The records of this work accord with surface indications thet the mineralized body has lerge cross section dinensions. The core ootained from a dow hole at a point some 600 feet beneati the surface outcrop is practically identical in character with that obtained near the surface. These findings ere in line with the plutonic origin of the invading magna and. normal geologic expectetion of downrard continuation of the formation elong the averues of its upwerd migration. A very large tornage, indeed, of cre not greetly varient in cheracter ifuil level to level rould appeor derintely indicated to occur in the Nentie deposit. 
gold, silver, nickel, cobalt and copper. The writer is confident that the returns are truly representative for they run in general accord with the variation of sulphide contents of the cores which he examined at the Nortbvest Testing Laooratory in Seattle, when the first set of assays were run.

From his study of the samples and assay regorts the water has roughly calculated that rock from the Mertie that carries 10;: sulphide would have a metalliferous content, considerably higher tinan the following:

\begin{tabular}{|c|c|c|c|c|}
\hline iETAI & CONTENT & PRICE & & VALUE \\
\hline Gold & .015028 & $\$ 20.00$ & $\$$ & 0.30 \\
\hline Silver & .10 & .50 & & 0.05 \\
\hline Copper & $0.3 \%$ & .18 & & 1.08 \\
\hline Nickel & $0.5 \%$ & .35 & & 3.50 \\
\hline Cobalt & $0.12,0$ & 2.50 & & 6.00 \\
\hline
\end{tabular}

Upon tinis basis a concentrate approaching pure sulphide sinould carmy metals worth at least $\$ 100.00 \mathrm{a}$ ton. It is believed that rock with less than 20,3 sulpinides rather than more would more truly represent sulpinide requirements for $\$ 10.00$ ore, and that a pure concentrate vould run correspondingly higher than 100.00 in metal value at the prices indicated.

Upon the basis of personal experlence in flotation mill practice the vriter feels confident thet a concentrate sufficientIy valuaje to bear shipoing costs can be made oy ilotation methods from the yertie ore. In view of the large tonnage indicated for the deposit a thorough investigation of flotation aranability of the ores is more than justified. Should the best concentra- 
tion attainable by flotation alone prove too lean for shipment, the tests should be extended to various methods of roasting and smelting.

\section{PROCEDURE SUGGESTED}

Under proper schedule of testing and progressive steps of practice, the full possibilities of the Mertie deposit can be developed without material financial risk at any time. The following steps are suggested, each to be taken upon the basis of satisfactory results of those preceding it:

1. Laboratory Plotation tests.

2. Standard equipment flotation tests (Government plant at Colorado School of Mines available).

3. Pilot mill, Kinimum unit of standard equipment inatalled in present bujldings under pover already available.

4. Laboratory smelting tests of concentrates.

5. Standarà equipment smelting tests.

6. Complete blocking out of adequate ore reserves.

7. Mine and mill expension to scale inalcated to be most economic in costs of production.

The cost of the earlier steps of such a program would be reduced to a low rigure by the facilities and equiprent already in place on tibe property. These include hous1ng, mine buildings, power, equipment for mining, transportation and miling of ores, assay of- 
fice, etc. Littie, if anything, other than the indicated flotation and smelting equipment would need to be added.

\section{SUIRIARY}

Gold-bearing quartz veins of moderate size and a suiphide ore deposit of large dimension containing rickel, cobalt, copper and sorde gold and silver occur on the Admiralty-Alaska property at Funter Bay, Azaska.

The deposits are of deep-seated igneous origin and may be expected to continue dowaward whout material change in character due to increasing depth.

It is believed that the sulphide ores will be found amenable to flotation metbods of concentration and that concentrates or material of proper grede for shipment can be produced from them.

Increasing use of nickel and cobalt in certain quality steel orcducts gives a better market outlook for the metals in the Mertie ore than would obtain if the values were more largely in copper and silver.

is schedule of progressive steps of testing and developraent is presented that is believed to offer extraordinary possibilities of large returns in relation to the capital risks involved. 